\title{
Univerzální racionalizace: Velké vyprávění Maxe Webera*
}

\author{
DIRK KAESLER**
}

\author{
Universal Rationalization: Max Weber's Great Narrative
}

\begin{abstract}
Among the "classic" diagnoses of modernity, the German scholar Max Weber is often ascribed the role of the creator of a "theory of rationalization." If there had to be one keyword for which Max Weber is constantly mentioned today, it would probably be "rationalization." This term denotes the vast context in the history of ideas which comprises Weber's alleged "theory" of a universal, occidental "rationalization." I myself do not really place this "theory," which has been attributed to Max Weber, into the portfolio of sociological theories in the strict epistemological sense, but rather into the reservoir of "Great Narratives," as Jean-François Lyotard has called them, "Les grands récits." Max Weber has bestowed his great narrative of universal, occidental "rationalization" upon the self-understanding of humanity by sociology as a discipline during its roughly 150 years of history up to the present day. Whoever wants to refer to this Great Narrative by Max Weber cannot forbear to reconstruct it from his texts. At best, only the outlines of this Great Narrative can be indicated here. We are talking about this vast context in the history of ideas which we contemporaries care to use for labeling Weber's vision of modernity. The concept of "rationalization," first emerging in Western and Northern Europe, followed by the transatlantic and universal rationalization for which Max Weber is so well known today, was in no way a guiding theme for the major part of his work. I will try to demonstrate this in the following five steps.
\end{abstract}

Keywords: Max Weber; "theory of rationalization"; Jean-François Lyotard; "Great Narratives"

DOI: $10.14712 / 23363525.2018 .53$

Mezi „klasickými“ diagnózami modernity se německému učenci Maxu Weberovi často připisuje role tvůrce „teorie racionalizace“, a to hlavně v Německu, kde Webera interpretují nejčastěji. Existuje-li termín, kterým je Max Weber dnes univerzálně známý, pak je to právě ona „racionalizace“. Označuje obsáhlý souhrn myšlenek, z něhož pramení jeho „teorie“ o univerzální, západní „racionalizaci“.

Koncept „racionalizace“, který se poprvé objevil v západní a severní Evropě, aby záhy překročil oceán a stal se univerzální racionalizací, jež Webera dnes tak proslavila, rozhodně nebyl hlavním tématem jeho díla. Pokusím se to dokázat v pěti krocích. Použiju vyjádření Maxe Horkheimera z roku 1939 - před vypuknutím druhé světové války - určený těm, kteří chtěli diskutovat o fašismu, aniž by brali v potaz kapitalismus: „Wer aber vom

\footnotetext{
* Tato přednáška byla proslovena 6. dubna 2017 na Pracovišti historické sociologie Fakulty humanitních studií Univerzity Karlovy, proto je v tomto textu dodržován přednáškový styl. Odkazy lze najít jak v mnou sepsaném životopise Maxe Webera [Kaesler 2014a], tak ve čtvrtém vydání mého úvodu k jeho dílu [Kaesler 2014b]. Tímto bych rád poděkoval Pracovišti historické sociologie a zvláště pak Jiřímu Šubrtovi za jeho pozvání a uspořádání přednášky.

** Dirk Kaesler, Institut für Soziologie, Philipps-Universität Marburg, Ketzerbach 11, D-35032 Marburg. E-mail: kaesler@uni-marburg.de. Homepage: <http://www.kaesler-soziologie.de>.
} 
Kapitalismus nicht reden will, sollte auch vom Faschismus schweigen." (Pokud nechcete hovořit o kapitalismu, o fašismu raději pomlčte. $)^{3}$

\section{Jestli nechcete mluvit o kapitalismu, raději pomlčte o „teorii racionalizace“ Maxe Webera}

Ten, kdo by si přál pochopit vnější a vnitřní vývoj Maxe Webera, klasika sociologie, musí ho nejprve umístit do kontextu kapitalistické globální ekonomiky 19. století, a to jak biograficky, tak charakterem jeho práce. Hovoříme tu o kosmopolitní buržoazii, ze které Weber pocházel.

Narodil se 21. dubna 1864 v pruském Erfurtu do idylického světa německé vyšší třídy, plného ekonomických, politických, sociálních, kulturních, a technologických vymožeností. Dostalo se mu solidní výchovy, žil v ekonomickém nadbytku a vyrůstal v rodině, kde vládly kosmopolitní vztahy, zkrátka vůbec nic mu nechybělo. Byl prvorozeným synem obklopeným široce rozvětvenou rodinou německo-anglické obchodní elity 19. století. Dědeček $\mathrm{z}$ otcovy strany byl prozíravým podnikatelem $\mathrm{v}$ textilu s mezinárodními obchodními partnery, druhý dědeček $\mathrm{z}$ matčiny strany rovněž patřil do jednoho $\mathrm{z}$ nejúspěšnějších německo-anglických obchodních rodů ve Frankfurtu nad Mohanem. Otec byl dlouho sloužícím členem pruské poslanecké sněmovny, zastupoval liberály, a byl trvalým členem německého Reichstagu, což z něho dělá výjimečně úspěšného profesionálního německého politika v době císaře Viléma. Jeho matka, dědička velkého majetku, se mohla stát zářivou hvězdou evropské vybrané společnosti, kdyby o to ovšem stála.

Bez ohledu na bohatě propojené rodinné vazby na kosmopolitní evropskou buržoazii, Weberovův osobní vývoj byl formován hodnotami pruských berlínských vyšších vrstev v období konce 19. a začátku 20. století. Když sám sebe označil za buržoazního badatele, byl si dobře vědom svého místa v systému se životním stylem, který uvažuje takto: „Jsem členem buržoazie a byl jsem vychován v příslušném hodnotovém i názorovém duchu.“

Od roku 1871 společenský kontext rozvíjející se kapitalistické společnosti Německé ř́iše poskytoval biografické prostředí, které nutně muselo mít vliv na prvorozeného syna, avšak vědecká analýza důsledků kapitalismu setrvává jako konstantní leitmotiv po celou dobu Weberova univerzitního vzdělávání, postdoktorského studia (1889), habilitace a docentury (1892), s návazným přechodem k profesuře (1893).

$\mathrm{V}$ počátcích vilémovského císařství vědecký rozbor důsledků kapitalismu nebyl zrovna inspirativní volbou pro studenta politických a společenských věd. Kapitalismus byl určujícím směrem pro překotný průmyslový růst německé říše během období „Gründerzeit“ - gründerství - zakládání velkých společností - kde mužští členové jeho rodiny hráli významnou roli a ženy se filantropickou činností snažily mírnit jeho neblahé důsledky.

\section{Pokud nechcete mluvit o protestantismu, raději pomlčte o kapitalismu}

Po dlouhé nečinnosti v do̊sledku vážné nemoci, zhruba v letech 1897-1904, se Max Weber opět pustil do akademického bádání, zpočátku ve své milované Itálii. Inspirovaný italským katolictvím se snažil přistupovat k dějinám, podmínkám a ekonomice křestanských klášterů analytickým způsobem. 
V říjnu 1903, ve věku 39 let, Max Weber definitivně skončil s univerzitními přednáškami, přičinou bylo narušené zdraví. Stal se honorárním profesorem na univerzitě v Heidelbergu, kde měl určité povinnosti, leč bez práva udělovat doktoráty a neměl vliv na vedení fakulty. Až do konce života žil jako soukromý badatel; umožňovaly mu to majetkové prostředky jeho ženy a matky. Byl spokojený, protože se osvobodil od vyučovacích povinností, které ho tížily, a nemusel plnit administrativní úkony. Zkrátka se mohl plně věnovat své vědě.

Weber se s důkladností sobě vlastní pustil především do problematiky původu kapitalismu, protože s jeho důsledky žil už řadu let. V té době svůj vlastní výzkum nepovažoval za fundamentální alternativu, ba ani jako protiargument velkého vyprávění Karla Marxe, jenž věřil ve vítězství „proletariátu“ a v nevyhnutelné zavedení „beztřídní společnosti“, což Webera koneckonců také zajímalo. Snažil se najít dodatečná vyvážení „materialistických“ teorií, jež v jeho době převládaly, hlavně se věnoval historickému objasnění původu kapitalismu. Weberovy otázky se výrazně dotýkají duchovních základů kapitalistické organizace ekonomického i společenského pořádku.

Jeho studia se zabývají hlavně kulturním významem protestanství a jeho vlivu na tvorbu ekonomické etiky, kterou Weber nazval duchem kapitalismu. Zde je třeba se zaměřit na pevné sociologické jádro této debaty. V esejích psaných v období 1904-1906 dnes nejznámějších z jeho díla, se Weber stále vrací k odvozené a složitě vypracované teorii elektivní spř́zněnosti mezi určitými typy a praktickými zásadami protestanství a západním, moderním racionálním průmyslovým kapitalismem. Weber věřil, že v duchovním podhoubí protestantských a kalvinistických sekt se nacházejí kořeny moderního kapitalismu.

První verze slavného pojednání „Protestantská etika a duch kapitalismu“ (1904/5), kde nastoluje problematiku sociostrukturálního a ideového původu moderního kapitalismu, byla sepsána dříve, než se Weber vydal všanc zkušenostem v Americe, aby tam konečně nalezl kulturu, v níž se moderní racionální průmyslový kapitalismus, jemuž věnoval tak velkou pozornost, předváděl v plné své kráse.

Na podzim 1904 se Max Weber se zúčastnil „Mezinárodního kongresu věd a umění, probíhajícího při světové výstavě v St. Louis. Od srpna až do listopadu procestovali se ženou Marianne velkou část Spojených států. Tato cesta hluboce ovlivnila jeho budoucí práci, podařilo se mu nejenom bezprostředně poznat různé protestantské sekty, mohl vidět, jak je organizovaná politická „mašinérie“, jaké je postavení amerického prezidenta, dokonce došlo i k přímé konfrontaci s americkým feministickým hnutím, poznával „rasové otázky“ a nebyl ušetřen ani zkušeností s byrokratizací, jak soukromého, tak veřejného života v USA.

\section{Chcete-li hovořit o kapitalismu formovaném protestanstvím, raději pomlčte o procesu racionalizace}

Max Weber považoval náboženství za základ své interpretace, kterak se podařilo prorazit racionálnímu průmyslovému kapitalismu západního typu. Dokládají to jeho práce o protestanství. Potom asi v roce 1911 obrátil svou pozornost i k mimoevropským náboženstvím, které klasifikoval jako nejdůležitější systémy regulace života. Započal svá studia standardním srovnávacím způsobem, hodlal sepsat tezi o obrovském významu sekularizované křest̉anské víry protestantského typu, která umožnila vytvořit duchovní podmínky pro moderní západní kapitalismus. 
Nicméně, během svého dlouhodobého a důkladného výzkumu čínských náboženství (konfuciánství a taoismu), indických náboženství (hinduismu a buddhismu) a starověkého judaismu, Weberova původní otázka, co jsou důsledky a jaký je původ kapitalismu, dramaticky změnila tvar. Když Weber započal svou kontrolní studii, řídě se heslem: tam, kde není protestanství, není ani kapitalismus - vedl v podstatě stále intenzivnější a nakonec nedokončenou analýzu univerzálních historických procesů „racionalizace“, jež prostupovala všechny aspekty lidského života.

Během dlouhých let studia důsledků a př́ičin kapitalismu Weber dospěl k názoru, že v historii existuje univerzálně aktivní a všeobecný vývoj: racionalizace. V počátečních testech podmínek a „kulturního významu“ tohoto vývoje, nalezl zhmotnění zmíněného konceptu ve všech segmentech společenské a historické reality, tedy v ekonomii, politice, zákonech, náboženstvích i kultuře. Racionalizace jako osudovost naší doby se stala Weberovým kolektivním označením pro všechny možné a zdaleka ne identické vedlejší procesy, jež stř́ídavě nazýval „byrokratizací”, „industrializaci“, „intelektualizaci“, „rozvojem racionálního průmyslového kapitalismu“, „specializací”, „objektivizací”, „metodifikací“, „ukázňováním“, „zklamáním“, „sekularizací“ či „dehumanizací".

Různorodost všech těchto nálepek prozrazuje, jak moc se Weber snažil integrovat extrémně heterogenní fenomény velmi odlišných perspektiv do kategorie, kterou si sám vymyslel, tedy do „racionalizace“. Z toho zdánlivě vyplývá, že nemá cenu formulovat koncept racionalizace v díle Maxe Webera. Jenže s výjimkou slavného „Předznamenání (1920) k prvnímu dílu jeho „Sebraných statí k sociologii náboženstvi“, neexistuje jediný text, kde by se sám Weber pokoušel něco podobného systematicky formulovat a termín se vyskytuje jen velmi zř́dka.

Ve Weberově díle „racionalizace“ v původní rovině znamená jednoduše pořádek a systematičnost. Rozmanitou a chaotickou snůšku pojmů s nekonečným množstvím spojnic je třeba uspořádat podle uměle vytvořených kritérií. Cesta takového systematického uspořádání vede k postupům, které Weber nazývá „racionalizace“.

Ve svých četných studiích a úvahách nakonec dospěl k názoru, že historické procesy systematického uspořádání, kterým dal název „racionalizace“ jsou jak univerzální, tak i nezadržitelná. Zpočátku vymyslel hypotézu „racionalizace“ pro entity, které mu připadaly vhodnější pro zavedení systematizace a pořádku, především pro ekonomii, zákonodárství, technologii, vědu a státní uspořádání. Shrnuto - jak to sám nazval - pro externí organizaci celého světa. Během rozvíjení teze o racionalizaci těchto okruhů, si pokládal tři důležité otázky, jež zůstávají v podstatě neměnné:

1) Proč zrovna „západní svět“ vyprodukoval zvláštní „racionálni““ kulturu univerzálního historického rozměru? Proč nedošlo k podobnému procesu „racionalizace“ v neevropských oblastech, zvláště v Asii, kde existují mnohem starší a mnohem rozmanitější kultury než ta na Západě?

2) Proč „racionálni““ věda a technologie, „racionálni““ průmyslový kapitalismus a „racionálně“ rozvinuté byrokratické státní organizace se objevily jen v moderní západní Evropě?

3) Jaké výhody tato „racionalizace“ přináší společnostem a vybraným skupinám, a jakou cenu tyto společnosti, sociální skupiny a dokonce jednotlivci, museli zaplatit za tento vývoj? 
V paralelním výzkumu se Max Weber soustředil ještě intenzivněji na oblasti, jež jsou všeobecně považovány za „iracionálni“ - tedy náboženství, etiku, umění, kulturu a sexualitu. Právě tyto sféry podle něho regulují vnitřní organizaci světa. Tyto okruhy lidské, sociální a historické reality byly - a nadále zůstávají - inspirativním pramenem překvapivých nápadů, spontánních hnutí, nadpřirozených sil, tajemství, zkrátka všeho, co je nevysvětlitelné, neboli iracionální, neuspořádané a chaotické.

Ale i tady Weber znovu zasáhl. Zaznamenal a určil socio-kulturní zaběhnuté procesy, jež uvedly do pořádku všechno možné, a rovněž zde našel „racionalizaci“.

1) Když zkoumal zvláštní „racionálnost“ západní hudby, její zaznamenávání do not, harmonie a instrumentální technika mu poskytla důkazy, že došlo k postupnému zániku mystických a „iracionálních“ kvalit umění, aby vzniklo provádění umění a postupně přijalo „racionální“ podobu.

2) Prozkoumával rozličná náboženství, kulty a druhy víry ve spásu, a to jak v čase, tak v kulturních okruzích. Všude objevoval jemu srozumitelná znamení, dokazující rozmáhající se „racionalizaci“ magického čarodějnictví a jeho proměnu v systematickou racionální teologii a církev. Podle Webera se racionalizace vztahuje jak k obsahu (teologie), tak k organizaci, tedy přeměnu sekt $\mathrm{v}$ církve.

3) Analyzoval historický vývoj sexuálního chování lidí - tedy vysoce individuální, neuspořádaný, zvírecí element v lidském jednání. Dokonce i zde nalezl sociálně protlačovanou racionalizaci. V postupném vylučování všech orgiastických kultů spojených s plodností a jejich nahrazení kněžstvem ve všech světových náboženstvích, měla spočívat systematická a racionální kanalizace sexuality. Od chaotických orgií, extáze a chaosu se postupně přecházelo v „ukázněnou“ sexualitu v manželském svazku, ve „skoro-manželském“ vztahu, v „ustáleném spojení“ či „milostném poměru“. Monogamní, polygamní, matriarchální či patriarchální uspořádání. Hlavně že zavládne pořádek.

Shrnuto: Kamkoliv se Max Weber podíval, všude nacházel nezvratné důkazy o velkém, světově historickém postupu racionalizace. Nicméně, nikdy nevěnoval pozornost tomu, jak proces racionalizace postupuje. Hledal ho, zkoumal, a soudil, že se jedná o unilineární vývoj sledující určitý vzorec. Opakovaná prohlášení, že historickou realitu lze analyticky popsat jako směs vzorově typizovaných konstrukcí, dále důraz, který vytrvale kladl na př́klady protichůdného vývoje, by mělo stačit, aby Weber nebyl považován za propagandistu slepé euforie pokroku. „Teorie modernizace“ ve smyslu „evoluční teorie“, podle níž by svět - nebo aspoň historie lidstva - měly být představovány jako pokračující cesta ke zdokonalování a k racionálnímu ovládnutí světa, by bylo groteskním nepochopením Weberova díla.

Webera celý život fascinovalo a vytrvale nutilo klást stejné otázky v rozličných sférách působnosti ohledně neuvěřitelného a zcela nepředvídaného procesu, který nazýval „racionalizace“ jemuž ale byly vytrvale házeny klacky pod nohy „neracionálními“ vlivy, jež ho vychylovaly z dráhy.

Proč od někoho, jako Max Weber, jenž se vytrvale vracel k otázce: „za jakou cenu“ existují tyto rozmanité procesy racionalizace, a sám si na to odpovídal skepticky až pesimisticky, nelze očekávat, že bude hájit „racionalizaci“ ve všech sférách lidského života jako něco pozitivního a žádoucího jen proto, aby obhájil dobu rozkvětu buržoazie. Weberova hluboce zakořeněná skepse a velký strach $\mathrm{z}$ „iracionálností “ - ve smyslu „nerozumnosti“ 
a „nelidskosti“ jež ve svém jádru obsahovaly „procesy racionalizace“, které nejenom neúměrně zvyšují efektivnost, ale i daleko sahající odlidštěnost, umistují Maxe Webera jako teoretika snažícího se vnést racionálno do iracionálna. Nemůže se vznést obvinění, že se stal jeho obhájcem. Toho, kdo neúnavně klade důraz na „iracionální motivy a důsledky „racionalizace“, témata, jež sám objevil i analyzoval, nelze nařknout, že je slepým uctívatelem vytrvale postupujících mechanismů „racionalizace“.

\section{Pokud nemáte vůli hovořit o dehumanizaci způsobenou byrokracií, pak raději mlčte o procesu racionalizace}

Tedy učenec jako Max Weber, který se neustále vyptával na „cenu“ racionalizačních procesů tak, jak je sám formuloval, a sám si odpovídal vysoce skeptickým a pesimistickým způsobem, nemohl vidět „racionalizaci“ všech sfér života jako správný krok vpřed. Hluboce zakořeněná skepse a hrůza $\mathrm{z}$ „nerozumnosti“ obsažená ve sledovaných procesech, mu dokazovaly, že touha po zvyšování efektivnosti nese s sebou „dehumanizaci“, „objektivizaci“, „depersonalizaci“ a „exanimaci“.

Ovládal ho strach, když sledoval nezastavitelný pochod kapitalismu a byrokratizace, zda bude vůbec možné zachránit pár zbytků „individualistických“ přístupů a zda bude vůbec možné, aby v budoucnosti existovala „demokracie“. Také vyslovoval obavy o stav kultury obecně a zároveň se dotazoval, jestli bude v budoucnu možné uplatnit svobodný způsob života. Na obojí si odpovídal velmi skepticky.

\section{Kulturní kritika a diagnostika času}

Zde končím rekapitulaci Weberova velkého vyprávění o univerzální „racionalizaci“ veškerých sfér lidského života. Až dodneška platí, že právě toto udělalo $z$ Webera primárního diagnostika modernity. Abychom to uzavřeli: Weberův výklad o neúprosné, osudové a univerzální „racionalizaci“ veškerých oblastí lidského života, podle toho, jak sám sledoval vývoj lidských společností, nebyl hlavním a převládajícím tématem jeho životní práce. Až na konci života a svého vědeckého bádání rozvinul tuto tristní vizi budoucnosti.

Dále abychom stručně shrnuli, že velké vyprávění Maxe Webera je příběhem apokalyptické ironie nezamýšlených důsledků. Radikální protestanti 16. a 17. století při hledání světských znamení, jež by podmínila jejich vykoupení z věčného zatracení, si vytvořili svůj kosmos názorů a způsobů chování, které nakonec vytýčily pevné mantinely podřízenosti a zotročení lidstva po celém světě.

Když nakonec došlo i na poslední zbytky původní piety, které pohltily také rozmanité instituce a lidé s nimi spojení, „moderní“, „racionální“ a „buržoazni“ průmyslový kapitalismus 19. a počátku 20. století se zmocnil vlády. Nedílné propojení kapitalistického uspořádání ekonomiky a mašinérie byrokratického pronikání do všech sfér života znamenalo ohrožení individuálních svobod a položilo základy k jejich konečné likvidaci.

Tak německý badatel Max Weber sepsal své ponuré „vyprávěni“ kousek po kousku na přelomu 19. a 20. století, přičemž svou vizi podroboval neustálým pochybnostem. $\mathrm{Na}$ začátku 21. století byla tomuto „vyprávění přisouzena sugestivní vysvětlující moc a tím bylo vytýčeno nad všechna ostatní vyprávění. At je tomu jakkoliv, Weber umíral s vědomím, že příší generace se nebudou probouzet do rozkvetlého léta, nýbrž do polární noci 
mrazivých temnot a utrpení. V neposlední řadě jenom dějiny, jež píše lidstvo, ukáží, zda se tyto neutěšené představy Maxe Webera naplní koncem 21. století.

Z angličtiny přeložila Jarka Stuchlíková

\section{Literatura}

Kaesler, Dirk [1988]. Max Weber. An Introduction to his Life and Work. Cambridge, Chicago: Polity Press, University of Chicago Press.

Kaesler, Dirk [2014a]. Max Weber. Preuße, Denker, Muttersohn. Eine Biographie. München: C. H. Beck. Kaesler, Dirk [2014b]. Max Weber. Eine Einführung in Leben, Werk und Wirkung. Frankfurt/Main, New York: Campus.

Dirk Kaesler préenášel v letech 1995-2009 jako profesor Philipsovy university v Marburgu. Pi̊sobí v oblasti dějin sociologie a sociální teorie, specializuje se na dílo Maxe Webera. Publikace z poslední doby jsou následující: Klassiker der Soziologie. 2 díly, 6. vyd. München: C. H. Beck 2007-2012 (ed.); Die protestantische Ethik und der Geist des Kapitalismus. 4. vyd. München: C. H. Beck 2013 (ed.); Max Weber. Eine Einführung in Leben, Werk und Wirkung. 4. vyd. Frankfurt am Main - New York: Campus 2014; Max Weber. Preuße, Denker, Muttersohn. Eine Biographie. München: C. H. Beck 2014. 